\title{
Anserine and glucosamine supplementation attenuates the levels of inflammatory markers in rats with rheumatoid arthritis
}

\author{
Jiang Minghao Zhao ${ }^{\dagger}$, Xiang Chen $^{\dagger}$, Ke Cheng, Qingming Shi $^{*}$ and Kun Peng ${ }^{*}$
}

\begin{abstract}
Rheumatoid arthritis (RA) is an autoimmune disorder that affects the joint synovium. Anserine is a functional dipeptide containing methylhistidine and $\beta$-alanine, and is present in the brain and skeletal muscle of birds and mammals. Glucosamine is an amino sugar used in the synthesis of glycosylated proteins and lipids. We evaluated the effects of anserine and glucosamine on RA. Rats were assigned into the control group, RA group, anserine group (1 mg/kg), glucosamine group (200 mg/kg), or anserine plus glucosamine group (anserine, $1 \mathrm{mg} / \mathrm{kg}+$ glucosamine, $200 \mathrm{mg}$ / $\mathrm{kg}$ ). Treatment was continued for 45 consecutive days and was administered orally. The serum levels of catalase, glutathione peroxidase (Gpx), superoxide dismutase (SOD), reduced glutathione (GSH), lipid peroxidation, uric acid, nitric oxide, ceruloplasmin, zinc, copper, prostaglandin $E_{2}\left(P_{G}\right)$, matrix metalloproteinase (MMP)-3, tumor necrosis factor (TNF)- $\alpha$, interleukin (IL)-1 $\beta$, and IL- 6 were assayed. The mRNA and protein levels of nuclear factor (NF)-KB and inducible nitric oxide synthase (iNOS) in synovial tissue were also determined. Anserine plus glucosamine significantly increased the catalase, SOD, Gpx, GSH, and zinc levels compared to the control, anserine, and glucosamine groups. Also, anserine plus glucosamine significantly reduced the PGE ${ }_{2}, \mathrm{MMP}-3, \mathrm{TNF}-\mathrm{a}, \mathrm{IL}-1 \beta$, and IL-6 levels compared to the control, anserine, and glucosamine groups. Furthermore, anserine plus glucosamine significantly reduced the mRNA and protein levels of NF-KB and iNOS compared to the control, anserine, and glucosamine groups. Therefore, supplementation of anserine plus glucosamine shows therapeutic potential for RA.
\end{abstract}

Keywords: Rheumatoid arthritis, Anserine, Glucosamine, Antioxidant, Rats

\section{Introduction}

Rheumatoid arthritis (RA) is an autoimmune disorder that affects the joint synovium. Swelling, inflamed joints, stiffness, and pain are the primary symptoms of RA (Choudhary et al. 2018). However, the pathogenetic mechanisms of RA are unclear. Delaying joint function disability is the major therapeutic approach for RA (Wang et al. 2014). Verschueren et al. (2009) have reported the alteration in working situation, normalized physical function and predictors of remission in early rheumatoid arthritis.

\footnotetext{
*Correspondence: KarynRiveradfc@yahoo.com; soygwz@163.com †iang Minghao Zhao and Xiang Chen equally contributed to this work. Department of Orthopaedics, The Second Affiliated Hospital of Nanchang University, No 1 Minde Road, Donghu District, Nanchang City 330000, JiangXi Province, China
}

Researchers have reported the use of biologics in the treatment of rheumatoid arthritis (Curtis and Singh 2011). Liu and Pope (2003) reported that the pannus and hyperplastic synovial tissue erode bone tissue and articular cartilage. Nakamura et al. (2007) showed that tumor necrosis factor (TNF)- $\alpha$, prostaglandin $\mathrm{E}_{2}\left(\mathrm{PGE}_{2}\right)$, nitric oxide $(\mathrm{NO})$, interleukin (IL)-1, and matrix metalloproteinases (MMPs) are important articular components. Therefore, induction of apoptosis and inhibition of cell proliferation are the primary therapeutic approaches for RA.

Anserine is a functional dipeptide containing methylhistidine and $\beta$-alanine found in the brain and skeletal muscle of birds and mammals (Kubomura et al. 2010). Tanida et al. (2010) evaluated the impact of anserine on the blood pressure and renal sympathetic nerve activity in rats. Sugiyama et al. (2005) reported that anserine 
augments the antitumor activity of doxorubicin. Kaneko et al. (2017) showed that anserine improves spatial memory and neurovascular-unit dysfunction in a mouse model of Alzheimer's disease. Kang et al. (2002) reported that anserine suppresses peroxyl radical-mediated modification of superoxide dismutase (SOD). Glucosamine is an amino sugar used in the synthesis of glycosylated proteins and lipids (Dai et al. 2018), which is produced using wheat, crustacean cytoskeletons, and corn as raw materials (Towheed et al. 2005). Glucosamine supplementation reduced the level of pain of osteoarthritic patients (Reginster et al. 2001). McAlindon et al. (2000) reported that glucosamine and chondroitin synergistically protect against osteoarthritis. Dai et al. (2018) showed that vitamin $\mathrm{E}$ and glucosamine exert a synergistic therapeutic effect against RA in a neonatal rat model. Thus, we evaluated the effect of anserine and glucosamine on RA.

\section{Materials and methods Rats and housing}

Male albino Wistar strain rats (170-200 g) were purchased from the Animal House of the Department of Orthopaedics, The Second Affiliated Hospital of Nanchang University, No 1 minde road, Donghu district, Nanchang city, JiangXi province, China and maintained in rat cages under a $12 / 12 \mathrm{~h}$ light/dark cycle at $60 \pm 5 \%$ relative humidity and $25 \pm 0.5{ }^{\circ} \mathrm{C}$. All procedures performed in studies involving animals were in accordance with the ethical standards of the Second Affiliated Hospital of Nanchang University at which the studies were conducted. Research proposal was approved on 03/02/2019.

\section{Model of RA}

RA was induced according to Dai et al. (2018; Wang et al. 2015). Briefly, complete Freund's adjuvant was administered to the rats intradermally. Type II bovine collagen and complete Freund's adjuvant were mixed at an equal ratio to prepare the adjuvant emulsion. The primary dose of emulsion $(1 \mathrm{mg} / \mathrm{ml})$ was administered to the rats intradermally, followed 3 weeks later by incomplete Freund's adjuvant as a booster.

\section{Group assignment}

Rats were assigned into the normal control group, RA group, anserine (A1131, Sigma-Aldrich, Shanghai, China) group (1 mg/kg), glucosamine (Sigma-Aldrich) group $(200 \mathrm{mg} / \mathrm{kg}$ ), or anserine plus glucosamine (anserine, $1 \mathrm{mg} / \mathrm{kg}$ + glucosamine, $200 \mathrm{mg} / \mathrm{kg}$ ) group. Treatment was continued for 45 consecutive days and was administered orally. Each group contained six rats.

\section{Biochemical markers}

At the end of treatment, rats were sacrificed following anesthetized by using $10 \%$ chloral hydrate. The blood was collected by cardiac puncture in a plain bottle, and from which serum was separated for the biochemical analysis. Then, rat was immediately dissected, and synovial tissues were excised and weighed. The serum levels of catalase, glutathione peroxidase (Gpx), SOD, and reduced glutathione (GSH) were determined as described previously (Weydert and Cullen 2010; Baydas et al. 2002). The serum lipid peroxidation level was measured as described elsewhere (Samarghandian et al. 2014). The serum levels of uric acid and nitric oxide (NO) were determined by calorimetric assay (Wu et al. 2018; Van Beezooijen et al. 1998). The serum levels of ceruloplasmin, zinc, copper, PGE $_{2}$, MMP-3, TNF- $\alpha$, IL-1 $\beta$, and IL- 6 were determined as described previously (Dai et al. 2018).

\section{Reverse transcriptase-polymerase chain reaction (RT-PCR)}

The mRNA and protein levels of nuclear factor (NF) $-\kappa B$ and inducible nitric oxide synthase (iNOS) in synovial tissue were determined according to Dai et al. (2018). Briefly, total RNA was isolated from synovial tissue and transcribed into cDNA, and NF- $\mathrm{kB}$ and iNOS mRNA was amplified using specific primers (Table 1 ).

\section{Western blotting}

Synovial tissue proteins were resolved by sodium dodecyl sulfate-polyacrylamide gel electrophoresis, transferred onto a membrane, and incubated with antibodies against iNOS (Abcam, ab3523) and NF-kB (Abcam, ab16502) for $12 \mathrm{~h}$. Finally, the blot was incubated with a horseradish peroxidase (HRP)-conjugated secondary antibody (ab6721, Abcam) for $60 \mathrm{~min}$ and the protein levels were assayed by enhanced chemiluminescence (ECL) (Zou et al. 2016).

\section{Immunohistochemistry}

At the end of the treatment, rats were anesthetized by $10 \%$ chloral hydrate, and sacrificed. The knee synoviums

Table 1 List of primers used in real-time polymerase chain reaction (qRT-PCR)

\begin{tabular}{llll}
\hline S. no & Gene name & Sense primer & Anti-sense primer \\
\hline 1 & iNOS & $5^{\prime}$-GTTCTCAAGGCACAGGTCTC-3' & $5^{\prime}$-GCAGGTCACTTATGTCACTTATC-3' \\
2 & NF-KB & $5^{\prime}$-GAAATTCCTGATCCAGACAAAAAC-3' & $5^{\prime}$-ATCACTTCAATGGCCTCTGTGTAG-3' \\
3 & GAPDH & $5^{\prime}$-TCCCTCAAGATTGTCAGCAA-3' & $5^{\prime}$-AGATCCACAACGGATACATT-3' \\
\hline
\end{tabular}


of their hind limbs were harvested and fixed in formalin for $24 \mathrm{~h}$, and embedded in paraffin. Next, the sections were deparaffinized, and rehydrated in xylene and a graded alcohol series. Hydrogen peroxide (3\%) was applied to inhibit endogenous peroxidase activity and bovine serum albumin (2\%) to block non-specific binding. Synovial tissue was treated with anti-iNOS (Abcam, ab3523) and anti-NF-kB (Abcam, ab16502) antibodies overnight and incubated with an HRP-conjugated antibody for $1 \mathrm{~h}$ (Balic et al. 2011). The iNOS and NF-kB expression was analyzed using a confocal microscope (FV300, Olympus, Japan).

\section{Statistical analysis}

Values are mean \pm standard deviation and were subjected to analysis of variance (ANOVA) with the Tukey post hoc test. The difference was taken as significant when $P<0.05$.

\section{Results}

Biochemical marker levels in RA rats

We evaluated the effect of anserine and glucosamine on RA. The SOD, catalase, Gpx, and GSH levels were reduced by $63.6 \%, 74.2 \%, 73.3 \%$, and $63.4 \%$, respectively, in the RA group compared to the normal control group (Table 2, $P<0.05$ ). Lipid peroxidation, NO, uric acid, ceruloplasmin, and copper were increased by $431.3 \#$ $288 \%, 200 \%, 126.7 \%$, and 92.3\%, respectively (Table 2, $P<0.05)$, while the zinc level was decreased by $158.3 \%$ (Table 2, $P<0.05$ ). The MMP- $3, \mathrm{PGE}_{2}$, TNF- $\alpha$, IL- $1 \beta$, and IL-6 levels were increased by $328.6 \%, 251.3 \%, 68.9 \%$,
$126.7 \%$, and $166.7 \%$, respectively (Table $2, P<0.05$ ). The mRNA and protein levels of NF- $\mathrm{kB}$ and iNOS were also significantly increased (Figs. 1 and $2, P<0.05$ ).

\section{Effect of anserine on biochemical and molecular markers in $R A$ rats}

The SOD, catalase, Gpx, and GSH levels were increased by $48.3 \%, 73.5 \%, 75 \%$, and $46.7 \%$, respectively, in the anserine group compared to the control group (Table 2, $P<0.05)$. Lipid peroxidation, NO, uric acid, ceruloplasmin, and copper were reduced by $35.3 \%, 24.7 \%, 24.6 \%$, $23.5 \%$, and $8 \%$, respectively, while the zinc level was increased by $25 \%$ (Table $2, P<0.05$ ). The MMP-3, $\mathrm{PGE}_{2}$, TNF- $\alpha$, IL- $1 \beta$, and IL- 6 levels were reduced by $23.8 \%$, $24.1 \%, 16.3 \%, 20.6 \%$, and $15.3 \%$, respectively (Table 2 , $P<0.05)$. The mRNA levels of NF-kB and iNOS were reduced by $18.5 \%$ and $13 \%$ respectively, whereas protein levels of NF- $\mathrm{kB}$ and iNOS were reduced by $>9 \%$ compared to the control group (Figs. 1 and 2, $P<0.05$ ).

\section{Effect of glucosamine on biochemical and molecular markers in RA rats}

The SOD, catalase, Gpx, and GSH levels were increased by $60.2 \%, 82.4 \%, 108.3 \%$, and $60 \%$, respectively, in the glucosamine group compared to the control group (Table $2, P<0.05$ ). Lipid peroxidation, NO, uric acid, ceruloplasmin, and copper were reduced by $47 \%, 36.1 \%$, $21.7 \%, 8.8 \%$, and $20 \%$, respectively, while the zinc level was increased by $16.7 \%$ (Table $2, P<0.05$ ). The MMP3, PGE $_{2}$, TNF- $\alpha$, IL- $1 \beta$, and IL- 6 levels were reduced

Table 2 Effect of anserine and glucosamine on the biochemical markers in rheumatoid arthritis induced rat model

\begin{tabular}{|c|c|c|c|c|c|}
\hline Markers & Normal control & Control & Anserine (1 mg/kg) & $\begin{array}{l}\text { Glucosamine } \\
\text { (200 mg/kg) }\end{array}$ & $\begin{array}{l}\text { Anserine ( } 1 \mathrm{mg} / \\
\mathrm{kg})+ \text { Glucosamine } \\
(200 \mathrm{mg} / \mathrm{kg})\end{array}$ \\
\hline $\mathrm{SOD}(\mathrm{U} / \mathrm{ml})$ & $365.2 \pm 21.4$ & $133.1 \pm 5.2^{* * *}$ & $197.4 \pm 7.5^{\#}$ & $213.2 \pm 11^{\#}$ & $313.4 \pm 16^{\# \#}$ \\
\hline Catalase (U/ml) & $13.2 \pm 0.8$ & $3.4 \pm 0.18^{* * *}$ & $5.9 \pm 0.2^{\#}$ & $6.2 \pm 0.3^{\#}$ & $10.6 \pm 0.5^{\# \# \#}$ \\
\hline $\mathrm{Gpx}(\mathrm{U} / \mathrm{ml})$ & $0.45 \pm 0.01$ & $0.12 \pm 0.005^{* * *}$ & $0.21 \pm 0.02^{\#}$ & $0.25 \pm 0.01^{\#}$ & $0.38 \pm 0.01^{\# \# \#}$ \\
\hline $\mathrm{GSH}(\mathrm{nmol} / \mathrm{ml})$ & $0.41 \pm 0.03$ & $0.15 \pm 0.01^{* * *}$ & $0.22 \pm 0.01^{\#}$ & $0.24 \pm 0.01^{\#}$ & $0.36 \pm 0.02^{\# \# \#}$ \\
\hline $\mathrm{MDA}(\mathrm{nmol} / \mathrm{ml})$ & $0.32 \pm 0.01$ & $1.7 \pm 0.1^{* * *}$ & $1.1 \pm 0.06^{\#}$ & $0.9 \pm 0.05^{\# \#}$ & $0.51 \pm 0.03^{\# \# \#}$ \\
\hline $\mathrm{NO}(\mathrm{ng} / \mathrm{ml})$ & $0.25 \pm 0.02$ & $0.97 \pm 0.05^{* * *}$ & $0.73 \pm 0.05^{\#}$ & $0.62 \pm 0.07^{\#}$ & $0.44 \pm 0.08^{\# \# \#}$ \\
\hline Uric acid (mg/ml) & $0.23 \pm 0.01$ & $0.69 \pm 0.03^{* * *}$ & $0.52 \pm 0.01^{\#}$ & $0.54 \pm 0.04^{\#}$ & $0.35 \pm 0.03^{\# \# \#}$ \\
\hline Ceruloplasmin (mg/ml) & $0.15 \pm 0.01$ & $0.34 \pm 0.01^{* * * *}$ & $0.26 \pm 0.01^{\#}$ & $0.31 \pm 0.01$ & $0.17 \pm 0.04^{\# \#}$ \\
\hline Copper ( $\mu \mathrm{g} / \mathrm{ml})$ & $0.13 \pm 0.01$ & $0.25 \pm 0.01^{* *}$ & $0.23 \pm 0.01$ & $0.21 \pm 0.01$ & $0.17 \pm 0.03^{\#}$ \\
\hline $\operatorname{Zinc}(\mu \mathrm{g} / \mathrm{ml})$ & $0.31 \pm 0.02$ & $0.12 \pm 0.01^{* * *}$ & $0.15 \pm 0.01$ & $0.14 \pm 0.01$ & $0.24 \pm 0.02^{\# \#}$ \\
\hline MMP-3 (ng/ml) & $52.5 \pm 3.2$ & $225 \pm 15^{* * *}$ & $171.3 \pm 7.1^{\#}$ & $156 \pm 8^{\#}$ & $81 \pm 6.4^{\# \# \#}$ \\
\hline $\mathrm{PGE}_{2}(\mathrm{pg} / \mathrm{ml})$ & $27.1 \pm 1.2$ & $95.2 \pm 5^{* * *}$ & $72.2 \pm 3.4^{\#}$ & $71.4 \pm 4.5^{\#}$ & $38.3 \pm 2^{\# \# \#}$ \\
\hline TNF-a (U/ml) & $2.9 \pm 0.12$ & $4.9 \pm 0.2^{* * *}$ & $4.1 \pm 0.1^{\#}$ & $3.9 \pm 0.13^{\#}$ & $3.2 \pm 0.2^{\# \#}$ \\
\hline IL-1 $\beta(\mathrm{U} / \mathrm{ml})$ & $1.5 \pm 0.01$ & $3.4 \pm 0.2^{* * *}$ & $2.7 \pm 0.05^{\#}$ & $2.5 \pm 0.12^{\#}$ & $1.8 \pm 0.05^{\# \# \#}$ \\
\hline IL-6 (U/ml) & $2.7 \pm 0.12$ & $7.2 \pm 0.21^{* * *}$ & $6.1 \pm 0.2^{\#}$ & $5.1 \pm 0.15^{\#}$ & $3.3 \pm 0.12^{\# \#}$ \\
\hline
\end{tabular}

*** $P<0.001,{ }^{\#} P<0.05,{ }^{\# \#} P<0.05$ and ${ }^{\# \#} P<0.05$ 


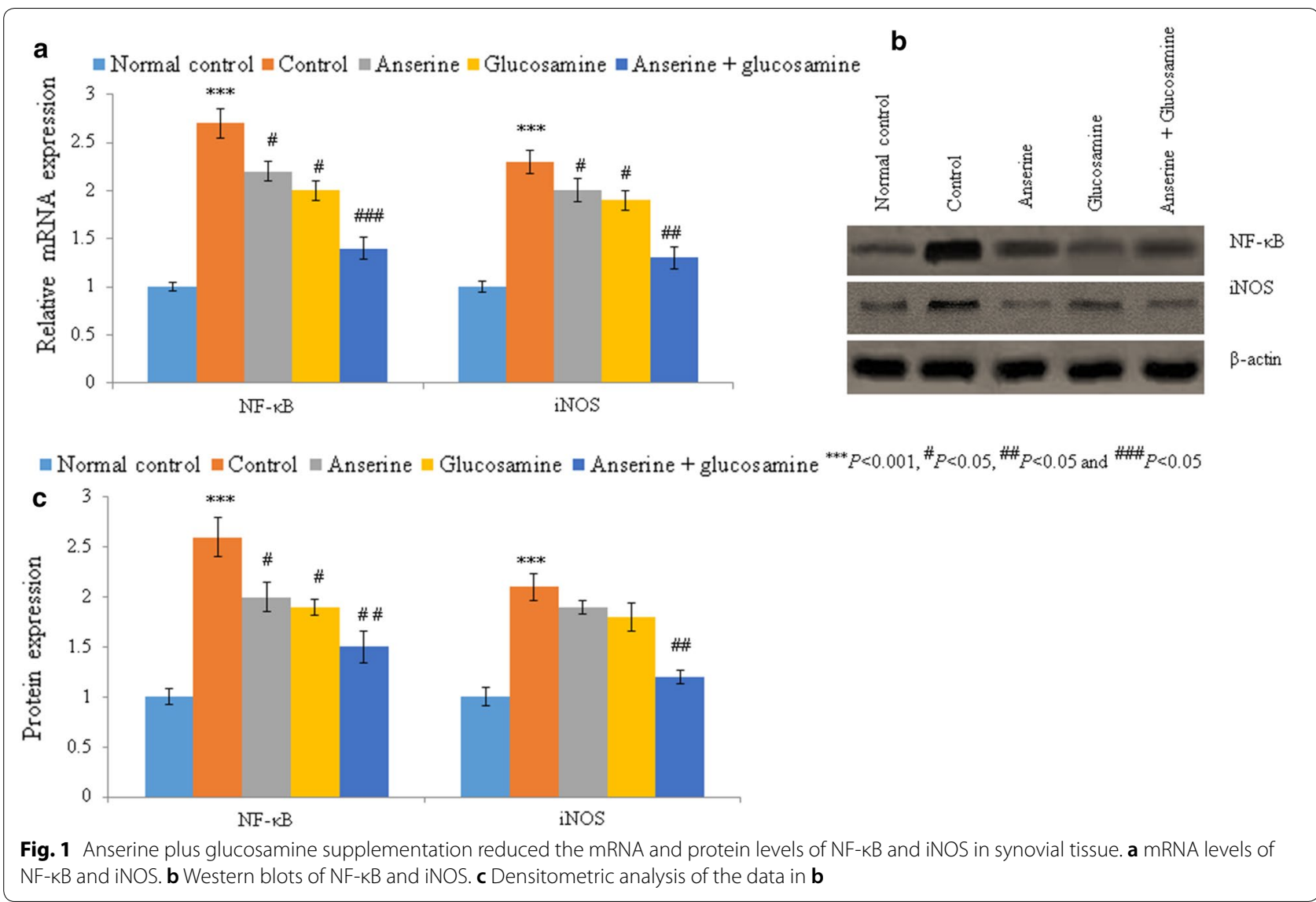

by $30.7 \%, 25 \%, 20.4 \%, 26.5 \%$, and $29.2 \%$, respectively (Table $2, P<0.05$ ). The mRNA levels of NF-kB and iNOS were reduced by $25.9 \%$ and $17.4 \%$ respectively, whereas protein levels of NF- $\mathrm{kB}$ and iNOS were reduced by $>13 \%$ in the glucosamine group compared to the control group (Figs. 1 and $2, P<0.05$ ).

\section{Synergistic effect of anserine plus glucosamine on biochemical and molecular markers in RA rats}

The SOD, catalase, Gpx, and GSH levels were increased by $135.5 \%, 211.8 \%, 216.7 \%$, and $140 \%$, respectively, in the anserine plus glucosamine group compared to the control group (Table $2, P<0.05$ ). Lipid peroxidation, NO, uric acid, ceruloplasmin, and copper were reduced by $70 \%, 54.6 \%, 49.3 \%, 50 \%$, and $32 \%$, respectively, while the zinc level was increased by $100 \%$ (Table $2, P<0.05$ ). The MMP-3, PGE 2 , TNF- $\alpha$, IL- $1 \beta$, and IL- 6 levels were significantly reduced in the anserine plus glucosamine group (Table 2, $P<0.05$ ). The mRNA and protein levels of NF- $\mathrm{kB}$ and iNOS were also significantly reduced in the anserine plus glucosamine group compared to the control, anserine, and glucosamine groups (Figs. 1 and 2, $P<0.05)$.

\section{Discussion}

We evaluated the effect of anserine and glucosamine on RA. A low level of cellular antioxidants and increased production of free radicals are implicated in RA (van Vugt et al. 2008). A higher rate of membrane fatty acid oxidation results in elevated levels of lipid peroxyl radicals. Ozturk et al. (1999) reported that the rate of lipid peroxidation is higher in patients with RA compared to healthy persons. Anserine and glucosamine have free radical-scavenging activity and inhibit lipid peroxidation (Wu et al. 2003; Tiku et al. 2007). Supplementation of glucosamine with vitamin $\mathrm{E}$ reduced lipid peroxidation in neonatal rats (Dai et al. 2018). In this study, anserine plus glucosamine decreased the level of lipid peroxidation compared to anserine, glucosamine, and the control.

Oxidative injury and inflammation increase the level of prostaglandin (Bae et al. 2003). MMP-3 produced by synovium-lining cells activates pro-collagenases, leading to destruction of cartilage proteoglycans and type IX collagen (Miller et al. 2009). The levels of $\mathrm{PGE}_{2}$ and MMP-3 in patients with RA are reduced by treatment with glucosamine (Nakamura et al. 2007). A high MMP-3 level is indicative of radiological damage and 


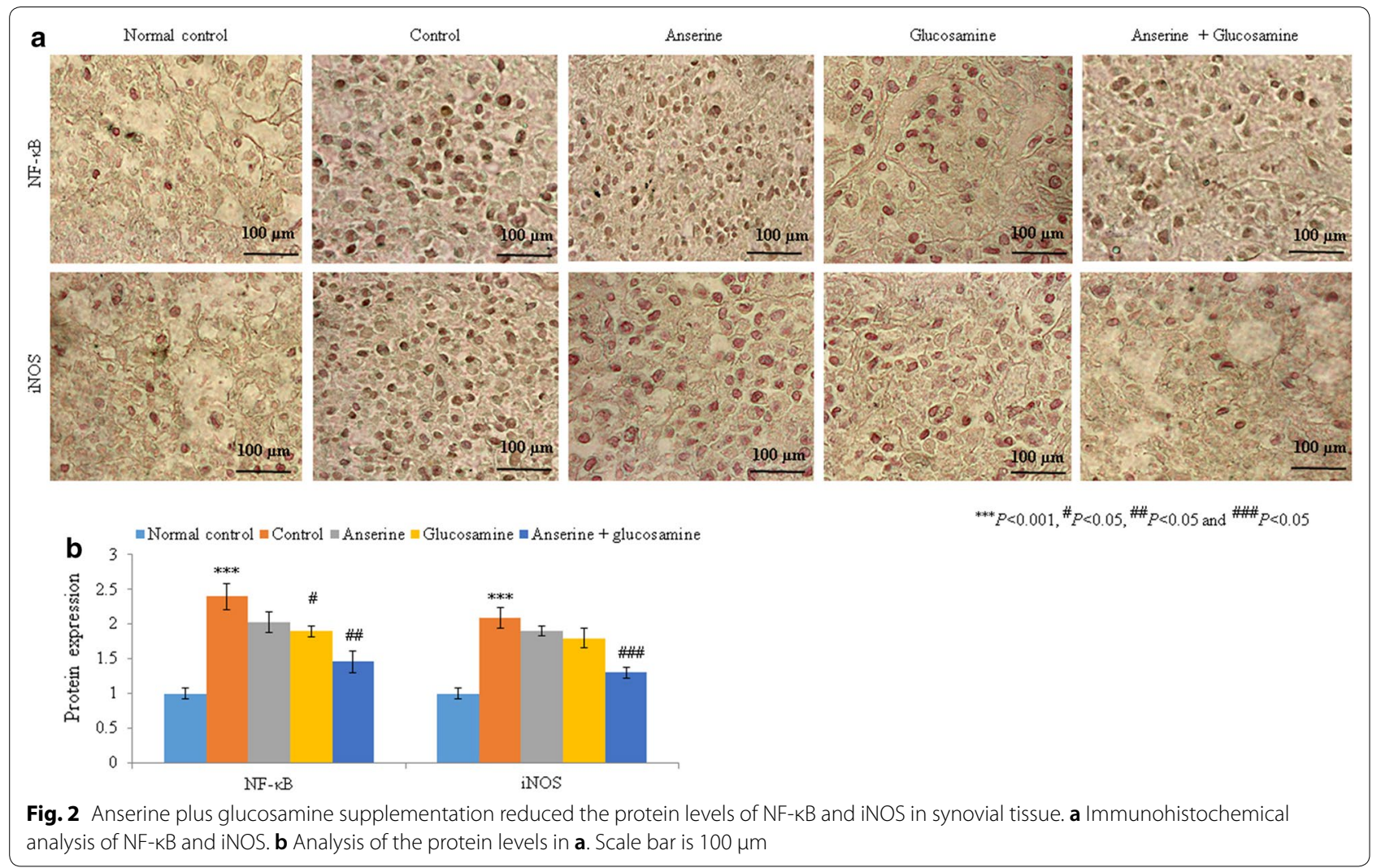

cartilage degradation (Ally et al. 2013). Supplementation of glucosamine with vitamin $\mathrm{E}$ reduced $\mathrm{PGE}_{2}$ and MMP-3 levels in neonatal rats (Dai et al. 2018). In this study, anserine plus glucosamine decreased the level of MMP-3 compared to anserine, glucosamine, and the control. Indeed, the MMP-3 level is reportedly reduced by glucosamine supplementation (Nakamura et al. 2002).

Antioxidants are closely correlated with the levels of oxidants and lipid peroxidation (Gupta et al. 2009). Reduced levels of catalase, SOD, Gpx, and GSH were noted in the control (RA) rats but were restored by anserine plus glucosamine to almost normal ranges. Dai et al. (2018) have reported the glucosamine with vitamin E supplementation restored the levels of catalase, SOD, Gpx, and GSH in neonatal rats. Sugiyama et al. (2005) reported that anserine augments the antitumor activity of doxorubicin. Kang et al. (2002) showed that anserine suppresses peroxyl radical-mediated SOD modification. Dai et al. (2018) reported that vitamin $\mathrm{E}$ and glucosamine exert a synergistic therapeutic effect against RA in neonatal rats. Ali et al. (2019) have reported the niclosamide supplementation exert anti-rheumatoid activity in collagen-induced arthritis in rat model. Higher levels of copper and ceruloplasmin (Amancio et al. 2003) and uric acid (Choe and Kim 2015) and a lower level of zinc were noted in rats with RA (Mierzecki et al. 2011), possibly due to an elevated level of IL-1 (Nemeth et al. 2002). Wang et al. (2019) have reported that the curcumin attenuates collagen-induced rat arthritis through apoptotic and anti-inflammatory effects. Researchers have reported that the evodiamine reduces adjuvant-induced arthritis in rats through the inhibition of synovial inflammation and restoring the Th17/Treg balance (Zhang et al. 2020). Supplementation of telmisartan with etanercept attenuates anemia associated with rheumatoid arthritis in rats (Hasanin and Mohamed 2020).

In this study, anserine plus glucosamine restored the levels of copper, ceruloplasmin, and zinc to almost the normal ranges. Taken together, our findings suggest that anserine plus glucosamine supplementation shows therapeutic potential for RA.

\section{Acknowledgements \\ None.}

\section{Authors' contributions}

$J \mathrm{M}, \mathrm{XC}$ and $\mathrm{KC}$ conducted experiments and collected data. QS and KP carried out data interpretation, review of literature and manuscript drafting. All authors read and approved the final manuscript.

\section{Funding}

None 


\section{Availability of data and materials}

Corresponding author could provide the all experimental data on valid request.

\section{Ethics approval and consent to participate}

All animal experiments were approved by the ethical committee of Department of Orthopaedics, The Second Affiliated Hospital of Nanchang University, No 1 minde road, Donghu district, Nanchang city, JiangXi province, China, 330000 .

\section{Consent for publication}

Not applicable.

\section{Competing interests}

The authors declare that they have no competing interests.

Received: 11 January 2020 Accepted: 3 March 2020

Published online: 20 March 2020

\section{References}

Ali AG, Faiq G, Ahmed M (2019) The anti-rheumatoid activity of niclosamide in collagen-induced arthritis in rats. Arch Rheumatol 34(4):426-433

Ally MM, Hodkinson B, Meyer PW, Musenge E, Tikly M, Anderson R (2013) Serum matrix metalloproteinase-3 in comparison with acute phase proteins as a marker of disease activity and radiographic damage in early rheumatoid arthritis. Mediators Inflamm 2013:183653

Amancio SOM, Chaud ADM, Yanaguibashi G, Esteves Hilario MO (2003) Copper and zinc intake and serum levels in patients with juvenile rheumatoid arthritis. Eur J Clin Nutr 57:706-712

Bae SC, Kim SJ, Sung MK (2003) Inadequate antioxidant nutrient intake and altered plasma antioxidant status of rheumatoid arthritis patients. J Am Coll Nutr 22:311-315

Balic MN, Rapp S, Stanzer H, Lin J, Strutz J, Szkandera MG, Daidone H, Samonigg RJ, Cote N (2011) Dandachi, Novel immunofluorescence protocol for multimarker assessment of putative disseminating breast cancer stem cells. Appl Immunohistochem Mol Morphol 19:33-40

Baydas G, Gursu MF, Yilmaz S, Canpolat S, Yasar A, Cikim G, Canatan H (2002) Daily rhythm of glutathione peroxidase activity, lipid peroxidation and glutathione levels in tissues of pinealectomized rats. Neurosci Lett 323:195-198

Choe JY, Kim SK (2015) Association between serum uric acid and inflammation in rheumatoid arthritis: perspective on lowering serum uric acid of leflunomide. Clin Chim Acta 1(438):29-34

Choudhary N, Bhatt LK, Prabhavalkar KS (2018) Experimental animal models for rheumatoid arthritis. Immunopharmacol Immunotoxicol 40(3):193-200

Curtis JR, Singh JA (2011) Use of biologics in rheumatoid arthritis: current and emerging paradigms of care. Clin Ther 33(6):679-707

Dai W, Qi C, Wang S (2018) Synergistic effect of glucosamine and vitamin E against experimental rheumatoid arthritis in neonatal rats. Biomed Pharmacother 105:835-840

Gupta S, Sodhi S, Mahajan V (2009) Correlation of antioxidants with lipid peroxidation and lipid profile in patients suffering from coronary artery disease. Expert Opin Ther Targets 13(8):889-894

Hasanin AH, Mohamed RH (2020) Telmisartan alone or in combination with etanercept improves anemia associated with rheumatoid arthritis in rats: a possible role of anti-inflammatory and reno-protective effects. Pharmacol Rep. https://doi.org/10.1007/s43440-019-00033-w

Kaneko J, Enya A, Enomoto K (2017) Anserine (beta-alanyl-3-methyl-L-histidine) improves neurovascular-unit dysfunction and spatial memory in aged AßPPswe/PSEN1dE9 Alzheimer's-model mice. Sci Rep 7:12571

Kang JH, Kim KS, Choi SY, Kwon HY, Won MH, Kang TC (2002) Protective effects of carnosine, homocarnosine and anserine against peroxyl radical-mediated $\mathrm{Cu}, \mathrm{Zn}$-superoxide dismutase modification. Biochim Biophys Acta 1570(2):89-96

Kubomura D, Matahira Y, Nagai K, Niijima A (2010) Effect of anserine ingestion on the hyperglycemia and autonomic nerves in rats and humans. Nutr Neurosci 13(3):123-128
Liu H, Pope RM (2003) The role of apoptosis in rheumatoid arthritis. Curr Opin Pharmacol 3:317-322

McAlindon TE, LaValley MP, Gulin JP, Felson DT (2000) Glucosamine and chondroitin for treatment of osteoarthritis: a systematic quality assessment and meta-analysis. JAMA 283:1469-1475

Mierzecki A, Strecker D, Radomska K (2011) A pilot study on zinc levels in patients with rheumatoid arthritis. Biol Trace Elem Res 143(2):854-862

Miller MC, Manning HB, Jain A (2009) Membrane type 1 matrix metalloproteinase is a crucial promoter of synovial invasion in human rheumatoid arthritis. Arthritis Rheum 60(3):686-697

Nakamura H, Shibakawa A, Tanaka M, Kato T, Nishioka K (2002) Effects of glucosamine hydrochloride on the production of prostaglandin E2, nitric oxide, and metalloproteases by chondrocytes and synoviocytes in osteoarthritis. Clin Exp Rheumatol 22:293-299

Nakamura H, Masuko K, Yudoh K, Kato T, Kamada T, Kawahara T (2007) Effects of glucosamine administration on patients with rheumatoid arthritis. Rheumatol Int 27:213-218

Nemeth I, Talosi G, Papp A, Boda D (2002) Xanthine oxidase activation in mild gestational hypertension. Hypertens Pregnancy 21:1-11

Ozturk HS, Cimen MY, Cimen OB, Kacmaz M, Durak I (1999) Oxidant/antioxidant status of plasma samples from patients with rheumatoid arthritis. Rheumatol Int 19:35-37

Reginster J, Deroisy Y, Rovati R, Lee LC, Lejeune RL, Bruyere E, Giacovelli O, Henrotin G, Dacre Y, Gossett JE (2001) Long-term effects of glucosamine sulphate on osteoarthritis progression: a randomized, placebocontrolled clinical trial. Lancet 357:251-256

Samarghandian S, Azimi-Nezhad M, Samini F (2014) Ameliorative effect of saffron aqueous extract on hyperglycemia, hyperlipidemia, and oxidative stress on diabetic encephalopathy in streptozotocin induced experimental diabetes mellitus. Biomed Res Int 9:208-257

Sugiyama T, Hatakeyama H, Inoue C, Sadzuka Y (2005) The effect of anserine, a novel biochemical modulator, on the antitumor activity of doxorubicin. Cancer Res 65:9

Tanida M, Shen J, Kubomura D, Nagai K (2010) Effects of anserine on the renal sympathetic nerve activity and blood pressure in urethane-anesthetized rats. Physiol Res 59(2):177-185

Tiku ML, Narla H, Jain M, Yalamanchili P (2007) Glucosamine prevents in vitro collagen degradation in chondrocytes by inhibiting advanced lipoxidation reactions and protein oxidation. Arthritis Res Ther 9(4):R76

Towheed TE, Maxwell L, Anastassiades TP, Shea B, Houpt J, Robinson V, Hochberg MC, Wells G (2005) Glucosamine for osteoarthritis. Cochrane Database Syst Rev 2:CD002946

Van Beezooijen RL, Que I, Ederveen AG, Kloosterbor HJ (1998) Plasma nitrate + nitrite level are regulated by ovarian steroids but do not correlate with trabecular bone mineral density in rats. J Endocrinol 159:27-34

van Vugt RM, Rijken PJ, Rietveld AG, van Vugt AC, Dijkmans BA (2008) Antioxidant intervention in rheumatoid arthritis: results of an open pilot study. Clin Rheumatol 27(6):771-775

Verschueren P, Esselens G, Westhovens R (2009) Predictors of remission, normalized physical function, and changes in the working situation during follow-up of patients with early rheumatoid arthritis: an observational study. Scand J Rheumatol 38(3):166-172

Wang K, Zhao L, Liu X, Hao Z, Zhou Y, Yang C, Li H (2014) Differential coexpression analysis of rheumatoid arthritis with microarray data. Mol Med Rep 10:2421-2426

Wang Y, Lu Y, Wang J, Shen Z, Liu H, Ma W, Zhang J, Ma X, Wang K, Meng $F$ (2015) Preparation and analysis of active rat model of rheumatoid arthritis with features of TCM toxic heat-stasis painful obstruction. J Tradit Chin Med Sci 2(3):166-172

Wang Q, Ye C, Sun S, Li R, Shi X, Wang S, Zeng X, Kuang N, Liu Y, Shi Q, Liu $R$ (2019) Curcumin attenuates collagen-induced rat arthritis via antiinflammatory and apoptotic effects. Int Immunopharmacol 72:292-300

Weydert CJ, Cullen JJ (2010) Measurement of superoxide dismutase, catalase and glutathione peroxidase in cultured cells and tissue. Nat Protoc 5(1):51-66

Wu HC, Shiau CY, Chen HM, Chiou TK (2003) Antioxidant activities of carnosine, anserine, some free amino acids and their combination. J Food Drug Anal 11:148-153 
Wu Y, Wang Y, Ou J (2018) Effect and mechanism of ShiZhiFang on uric acid metabolism in hyperuricemic rats. Evid Based Complement Alternat Med 2018:6821387

Zhang H, Yin L, Lu M, Wang J, Li YT, Gao WL, Yin ZS (2020) Evodiamine attenuates adjuvant-induced arthritis in rats by inhibiting synovial inflammation and restoring the Th17/Treg balance. J Pharm Pharmacol. https://doi.org/10.1111/jphp.13238
Zou L, Zhang G, Liu L, Chen C, Cao X, Cai I (2016) Relationship between PI3K pathway and angiogenesis in CIA rat synovium. Am J Transl Res 8(7):3141-3147

\section{Publisher's Note}

Springer Nature remains neutral with regard to jurisdictional claims in published maps and institutional affiliations.
Submit your manuscript to a SpringerOpen ${ }^{\circ}$ journal and benefit from:

- Convenient online submission

- Rigorous peer review

- Open access: articles freely available online

- High visibility within the field

- Retaining the copyright to your article

Submit your next manuscript at $\boldsymbol{\nabla}$ springeropen.com 